\title{
Kirurgisk behandling av pilonidal sykdom
}

\author{
Sammendrag \\ Bakgrunn. Pilonidal sykdom er relativt \\ vanlig og ses oftest hos unge menn. \\ Tilstanden forekommer enten som \\ akutte abscesser eller som kronisk \\ sekresjon av puss fra betente hud- \\ ganger i glutealregionen. Et stort antall \\ kirurgiske metoder benyttes, og residiv \\ er vanlig. Vi presenterer en oppdate- \\ ring av kirurgisk behandling for piloni- \\ dal sykdom.
}

Materiale og metode. Artikkelen er basert på en usystematisk gjennomgang av litteratur i PubMed relatert til kirurgisk behandling av pilonidal sykdom samt egne kliniske erfaringer.

Resultater. Akutt abscessdanning må dreneres kirurgisk før utvidet kirurgi kan vurderes. Vedvarende, residiverende eller sekrerende pilonidal sykdom bør opereres med en definitiv prosedyre. En nylig publisert metaanalyse viser at fjerning av hudforandringer ved reseksjon av en asymmetrisk hudlapp og primær lukning av såret til side for glutealkløften (Bascoms kløft-løft-operasjon) synes å gi færrest residiv, kortest tid til tilheling og færrest infeksjoner.

Fortolkning. Bascoms prosedyre bør være foretrukket kirurgisk behandling for pasienter med pilonidal sykdom i kronisk forløp.
Deler av artikkelen er delvis basert på en artikkel av sisteforfatter publisert i Nature Clinical Practice in Gastroenterology \& Hepatology (1)

> Se også side 920
Christian Rushfeldt

ch-rushf@online.no

Avdeling for gastroenterologisk kirurgi

Universitetssykehuset Nord-Norge

9038 Tromsø

Kjetil Søreide

Kirurgisk avdeling

Stavanger universitetssjukehus

og

Institutt for kirurgiske fag

Universitetet i Bergen

Akutte abscesser og kronisk betennelse i hudganger som oppstår i glutealkløften, betegnes gjerne som «pilonidal sinus», "sakral cyste» eller «tvilling» på folkemunne. Mer riktig er nok betegnelsen «pilonidal sykdom» («pilonidal disease») fra engelsk litteratur. At tilstanden har fătt tilnavnet «tvilling» på folkemunne, henspeiler nok på tidligere tanker om at dette skulle være et medfødt anlegg eller rester av embryologisk vev. «Pilonidal» betyr enkelt oversatt «nøste eller rede av hår». Henvisningen til hår gjenspeiler de funn som ofte gjøres ved kirurgi eller også mikroskopi av kirurgisk fjernet hud (2-4). Pilonidal sykdom kan presentere seg akutt med smertefulle abscesser og som mer kronisk forløpende hudbetennelse med pussekresjon. Dette er en relativt vanlig sykdom i den unge, mannlige delen av befolkningen, og kan for noen bli et hygieneproblem som kan være sosialt hemmende grunnet illeluktende sekret.

Historisk sett har kirurgisk behandling vært forbundet med et stort antall brukte metoder med varierende resultat og tilbakefall hos opptil $40 \%$ av pasientene (5). Det benyttes fortsatt en rekke kirurgiske teknikker med tilsvarende varierende resultater $(5-10)$. Tilstanden har ikke vært omtalt i Tidsskriftet siden tidlig i 1990-årene (11). Hensikten med denne artikkelen er å gjøre rede for ny forståelse av sykdommen samt hva som i dag anses å være den beste kirurgiske behandlingen for denne pasientgruppen.

\section{Materiale og metode}

Oversiktsartikkelen er basert på usystematisk gjennomgang av litteratur i PubMed relatert til kirurgisk behandling av pilonidal sykdom, med vekt på metaanalyser, randomiserte studier og prospektive studier fra de siste fem årene (t.o.m. februar 2009). Historiske artikler er tatt med der disse gjengir viktig bakgrunnsinformasjon. I tillegg baseres presentasjonen på egne kliniske erfaringer.
Vi fant kun et begrenset antall randomiserte studier, prospektive studier, systematiske oversikter eller metaanalyser relatert til behandling av pilonidal sykdom. Artikkelen er i hovedsak basert på disse $(9,12-19)$.

\section{Insidens og risikofaktorer}

Fra en norsk studie er det rapportert en insidens på 26 per 100000 innbyggere (3), med median alder ved diagnose rundt 20 år. Tilstanden forekommer 2-3 ganger hyppigere hos menn enn hos kvinner $(3,20)$. Pilonidal sykdom varierer mellom befolkningsslag, og forekom hos opptil $9 \%$ av tyrkiske soldater i førstegangstjeneste, hvorav halvparten var asymptomatiske (21). Overvekt, hirsutisme (hårrik region), familiær forekomst, stillesittende livsstil (kontorarbeidende, sjåfører og tilsvarende) er assosiert med sykdommen i noen studier, men ikke $\mathrm{i}$ alle $(3,21-23)$. Røyking synes å forsinke sårtilheling og øke komplikasjonsfaren etter kirurgi (24).

\section{Patogenese}

Det er bred enighet om at pilonidal sykdom ikke er en medfødt, men en ervervet tilstand $(2,21,23,25-27)$. Likevel kan andre medfødte anatomiske forhold som kroppsbehåring og dyp glutealkløft predisponere for tilstanden, noe som også kan forklare den store forskjellen i insidens mellom menn og kvinner og mellom ulike befolkninger $(3,21)$. En skisse til hvordan en trinnvis utvikling av sykdommen forekommer fra betente hårsekker, til dype, pussekrerende ganger er gjengitt i figur 1. Den utløsende årsaken antas å være en hudskade, noe som huden i gluteal-

\section{Hovedbudskap}

- Pilonidal sykdom er en vanlig tilstand som hovedsakelig forekommer blant unge menn

- Tilstanden presenteres ved akutte, smertefulle abscesser (tidlig fase) og etter hvert vedvarende, kronisk pussekresjon (sen fase)

- Kirurgisk behandling må være basert på forståelse av underliggende årsak i glutealkløftens $ø$ vre hudlag

- Asymmetrisk reseksjon av hud med primær lukning og flytting av hudlapp til siden for glutealkløften gir bedre resultater enn andre kirurgiske teknikker 
kløften er spesielt utsatt for gjennom trykk (ved å sitte) eller gnidning hud mot hud (bevegelse). Sykdommen starter oftest i form av infiserte hår- eller talgsekker i interglutealkløften (rumpesprekken) som grunnet press og gnidning mellom hudflatene ikke får tømt seg, men presses ned i underliggende subcutis og gir innpass for bakterieflora som danner puss og abscess. Grunnet den dype kløften, det fuktige miljøet og forekomsten av bakterier, bl.a. som følge av nærhet til anus, er det gode vilkår for infeksjoner og tilsvarende dårlige forhold for sårtilheling. I akuttfasen kan små eller store abscesser oppstå, og disse må da åpnes og dreneres dersom de ikke åpner seg spontant. Gjentatte abscessdanninger kan medføre permanente drenasjeåpninger i huden (sinuser) der kanalgangen kan bli epitelialisert, og der man ved eksisjon finner hår og talgkjertler dratt inn i lesjonen $(1,2,28)$.

\section{Behandling}

Akutte abscesser

Akutt kirurgisk behandling for pilonidal sykdom er nødvendig ved akutte abscesser som ikke har sprukket av seg selv og derfor må åpnes og dreneres for puss. Dette kan gjøres i lokalbedøvelse eller narkose, alt etter størrelse på abscessen. For å unngå at hudåpningen etter incisjon $\mathrm{av}$ en sentral abscess utvikler seg til en permanent sinusåpning med vedvarende sekresjon, anbefaler Bascom at incisjonen ved akutte abscesser legges 1-2 cm lateralt for den sårbare midtlinjen i glutealkløften (2). Fra den laterale incisjonen tunnelerer man seg da på skrå inn mot abscessen i midten, slik at denne dreneres indirekte. Vi har gode, kliniske erfaringer med denne teknikken. Men, dersom huden over abscessen allerede er tynn, nekrotisk og sprekkeferdig, er det ingen grunn til å gå inn lateralt.

Sekundær, tilhelende kirurgi vil senere måtte vurderes for de som ikke tilheler eller som får nye abscesser. For å fange opp disse pasientene vil det være nyttig med en poliklinisk kontroll 3-4 måneder etter det akutte forløpet.

\section{Kronisk sekresjon}

eller residiverende abscesser

Den viktigste indikasjonen for operasjon av pilonidal sykdom er ikke funn av sinusåpninger i rima internates, men symptomene som disse gir. Residiverende abscessdanninger med påfølgende rupturer kan være smertefulle for pasienten og gjøre kirurgisk behandling nødvendig. Sinusene er ofte kolonisert av bakterier (29), og for noen kan illeluktende og vedvarende pussekresjon være et problem. I tillegg beskriver pasientene hygieniske utfordringer med stadige skift av undertøy eller bruk av absorberende innlegg pga. pussekresjon. Tilstanden helbreder seg sjelden spontant, men rolige faser med lite eller ingen sekresjon kan av og til erfares etter sykdomsdebut, som regel i form av en primær abscessdanning. Av denne grunn kan det være riktig å avvente symptomutviklingen noen måneder etter at tilstanden har debutert før man opererer.

\section{Kirurgiske teknikker}

Under den annen verdenskrig ble sykdommen kalt for «jeep disease», da den rammet unge soldater i en situasjon med dårlig hygiene og til dels mye stillesitting i kjøretøy (30). Behandlingen var vid eksisjon av hud og dype vevslag ned til halebeinet, noe som etterhvert ble forbudt av den amerikanske øverstkommanderende for krigskirurgi fordi metoden førte til lange sykefravær og hyppige residiv. Utvidet, dyp eksisjon av vev ned til den presakrale fascie og sekundær sårtilheling har likevel vært - og er fortsatt - en hyppig brukt metode for denne sykdommen både i Norge og i mange andre land, noe som innebærer et mutilerende inngrep med lang sårtilheling. Resultatene er ofte like nedslående som de som ble observert fra den annen verdenskrig, med lang rekonvalesenstid for pasienten, stort sykefravær og hyppige residiv. Prinsippene for korrekt kirurgisk behandling ble imidlertid utviklet, blant annet gjennom systematiske studier utført av den amerikanske kirurgen John Bascom (10,31, 32). Han videreutviklet Karydakis' teknikk basert på en asymmetrisk, elliptisk hudeksisjon og mobilisering av en hudlapp fra motsatt side av rima internates (26).

Det finnes i dag en rekke ulike kirurgiske teknikker for behandling av pilonidal sykdom og disse kan inndeles i to hovedgrupper. Den ene gruppen består av ulike symmetriske/midtlinje-teknikker inkludert vid og smal eksisjon med eller uten primær lukning av såret (18), mens den andre omhandler ikke-midtlinje og asymmetriske teknikker, inkludert Z-plastikker, rhomboid plastikk (Limberg-lapp), skrå (oblique) eksisjon samt Bascoms og Karydakis' plastikker (9). Én metaanalyse $(13,14)$ og én systematisk over- sikt over publiserte data fra en 35 -års periode på over 10000 pasienter (9) konkluderer med at de asymmetriske teknikkene gir bedre resultater i form av færre residiv, kortere tilhelingstid og færre sårinfeksjoner $(13,14$, 19). Blant de asymmetriske teknikkene anbefaler Petersen og medarbeidere Karydakis' og liknende teknikker, fordi disse vurderes som enklest å utføre (9). Av disse er Bascoms kløft-løft-teknikk en videreutvikling og en forenkling av Karydakis teknikk. Mens Karydakis beskriver fiksering av en tykk lapp til den sacrococcygeale fascie, beskriver Bascom en tynnere hudplastikk der de dypere vevslag ikke mobiliseres (31) (fig 2). Bascom rapporterer om en primær tilhelingsrate på $90 \%$ hos pasienter etter tidligere mislykket kirurgi med andre teknikker, og en $100 \%$ tilhelingsrate etter små revisjoner på de resterende pasientene $(10,32)$.

Et hovedelement i Bascoms studier (10, 31,32 ) er at sykdommens årsak og manglende evne til spontan tilheling er betinget av de patofysiologiske forhold som oppstår i det nærmest intertriginøse hudområdet $\mathrm{i}$ de dype deler av den intergluteale kløften. Hovedpoenget er å remodellere glutealkløften som er den indirekte årsaken til at sykdommen er så vanskelig å helbrede. Dette gjøres ved at glutealkløften løftes opp (cleftlift) og lukkes (cleft-closure) slik at den endrer utseende fra en dyp V-dal til en flat U-dal (fig 3). Derved kommer den påvirkede huden opp i fri luft. Endringen i tenkemåte besto altså $i$ at sykdommen er forankret $i$ selve huden i kløften og ikke i de dypere vevslag, slik tankegangen bak tidligere radikal, dyp eksisjonskirurgi var.

Bascoms egen indikasjon for asymmetrisk utflating av glutealkløften var såkalt refraktær sykdom, dvs. pasienter som ikke var blitt helbredet etter tidligere kirurgi med andre teknikker. Flere, blant annet Rushfeldt og medarbeidere, mener i sine studier (12, 20,33) at teknikken med fordel også kan

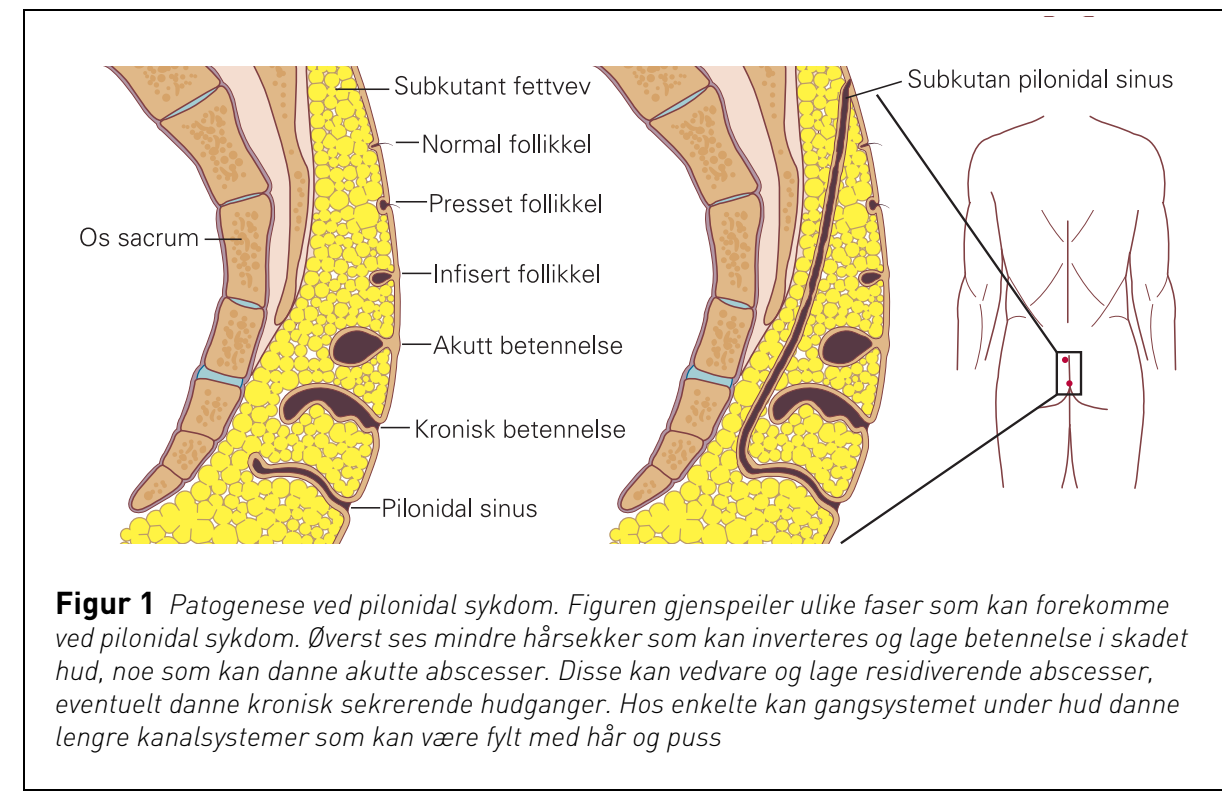



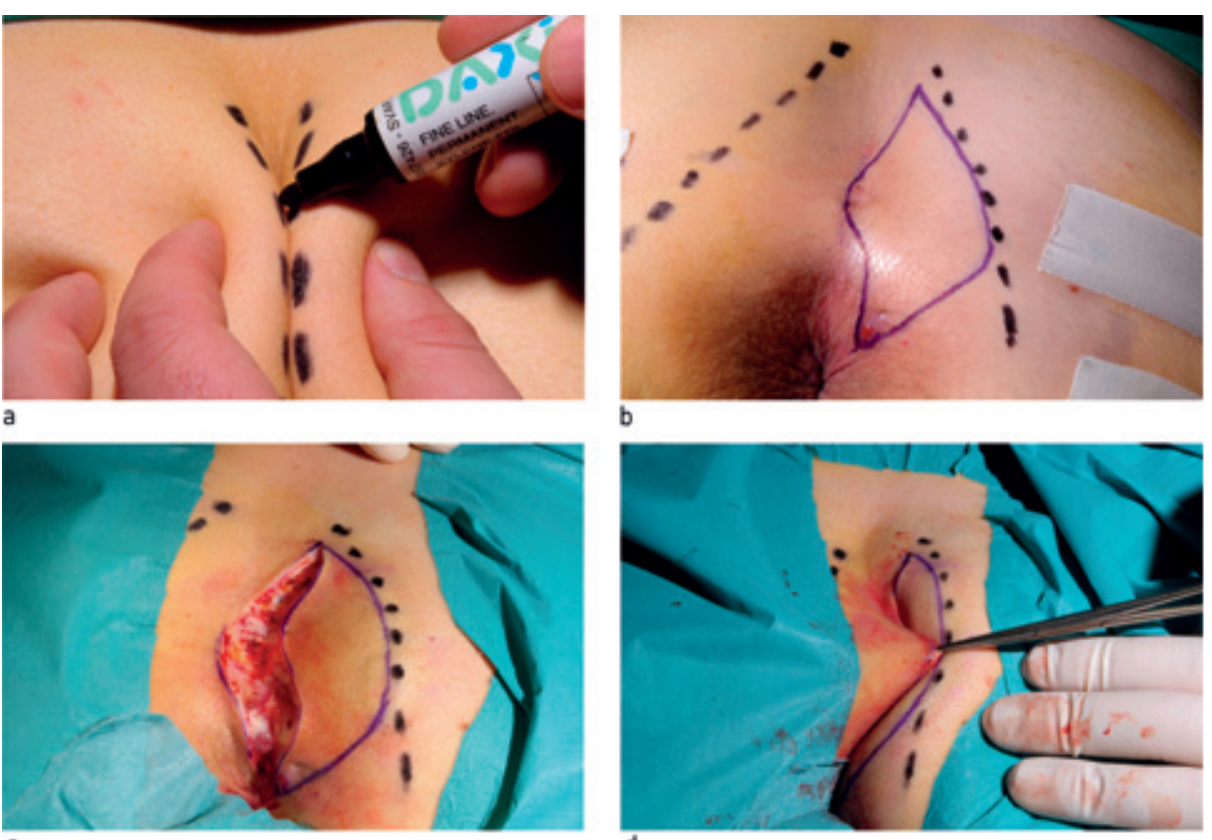

c

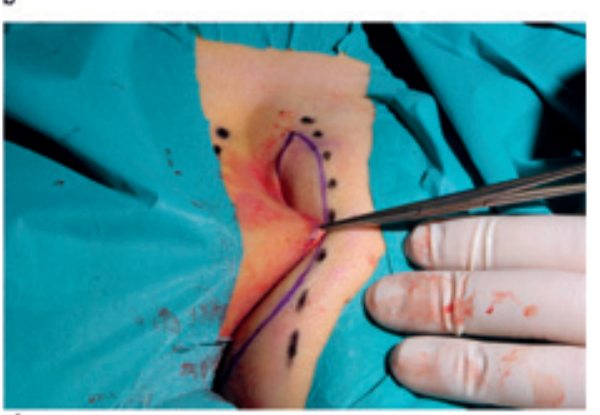

d
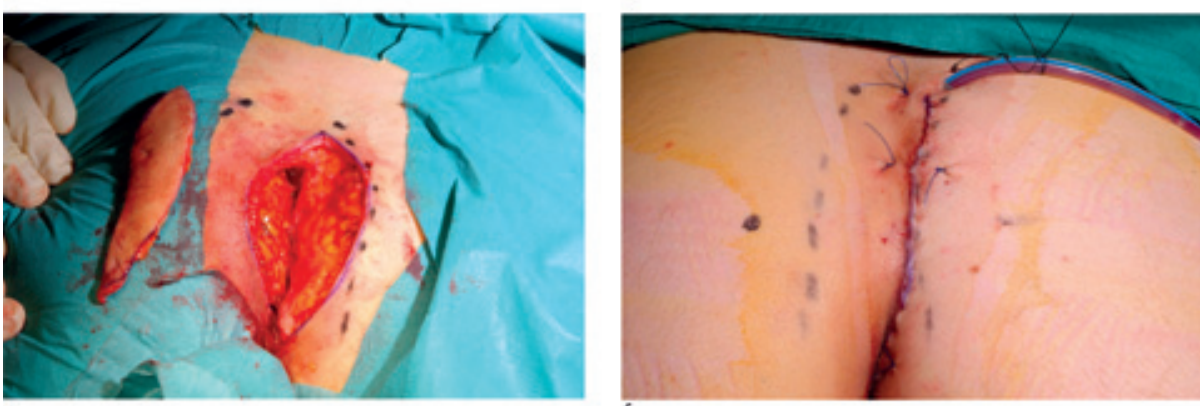

Figur 2 Trinnvis illustrasjon av kirurgisk behandling av pilonidal sykdom. al Midtlinjen markeres med tusj med pasienten i en nøytral posisjon. b) Kløften eksponeres ved at nates dras ut til sidene med tape. Det lages en tilnærmet elliptisk formet skisse av preparatet som innbefatter den del av midtlinjen som inneholder sinusåpninger. c) Den mediale side av ellipsen åpnes ned til subkutant fettvev. Huden undermineres (1-2 mm under dermis) under hele preparatet og i et tilsvarende område på motsatt side. Dypere vevslag røres ikke med unntak av ev. abscesser/håransamlinger som fjernes. dlTapen som er festet til nates, løsnes slik at kløften lukker seg. Med et lett drag i huden på motsatt side av preparatet kontrollerer man at det er nok hud til å dekke kløften, og skissen justeres om nødvendig. el Preparatet fjernes ved at den laterale siden av ellipsen skjæres igjennom. f) Det legges inn et dren i bunnen av såret før det lukkes subkutant i to lag med fortløpende resorberbar sutur. Huden lukkes med en fortløpende, intradermal ikke-resorberbar sutur som festes utenfor såret på tre steder og fjernes etter ti dager.

Drenet fjernes etter én dag
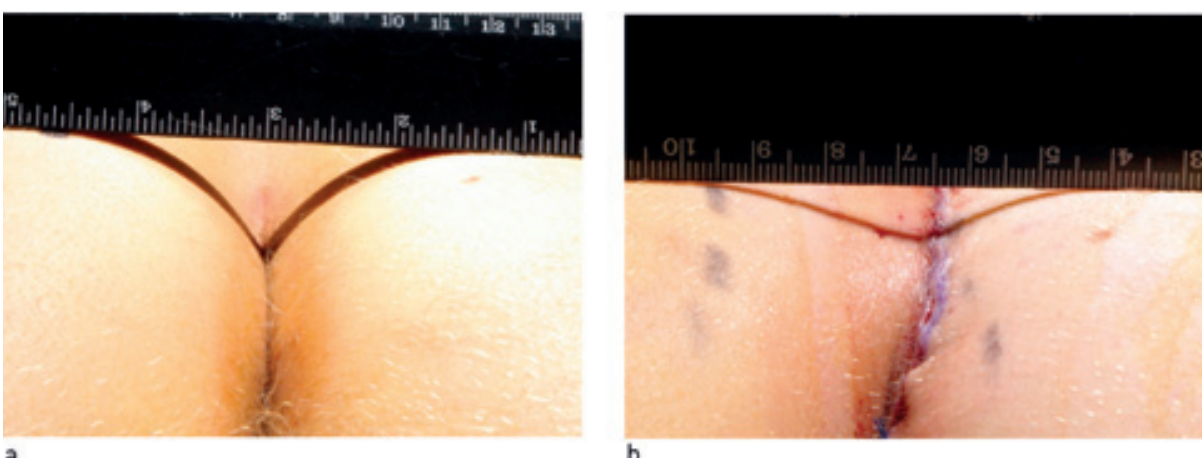

Figur 3 Avflatingen av den dype intergluteale kløften, før (a) og etter (b) Bascoms kløft-løft-operasjon

benyttes som en enhetlig metode for behandling av alle symptomgivende sykdomstilfeller, dog med noe mindre omfattende plastikker hos pasienter med enten bare én sinus eller få sinuser som ligger nær hver- andre (fig 4). Ifølge Bascoms studier vil omtrent $10 \%$ av pasientene med refraktær sykdom ha behov for en mindre revisjon eller en supplerende operasjon pga. sårinfeksjon og residiv $(10,32)$. Andre kirurgers erfaringer med Bascoms kløft-løft-teknikk på både enkle og kompliserte tilstander viser ingen residiv på oppfølgingstidspunktet, men forsinket sårtilheling hos åtte pasienter, manglende sårtilheling hos to pasienter og ett tidlig residiv hos en av totalt 120 pasienter $i$ tre studier med median oppfølgingstid på 10-36 måneder $(12,33,34)$.

\section{Dagkirurgisk prosedyre og bruk av antibiotika}

Bascoms operasjon kan utføres dagkirurgisk i lokalanestesi med adrenalin supplert med dyp sedasjon $(10,20)$. Bruk av diatermi unngås for å få minst mulig vevsnekrose. Én studie viser nytte av per- og postoperativ antibiotikaprofylakse for å redusere sårinfeksjoner ved pilonidal kirurgi med primær lukning (15), en annen studie viser ingen nytte av en enkel dose peroperativ antibiotikaprofylakse (16), mens en tredje studie ikke viser noen forskjell på om antibiotika gis $i$ én dag eller fire dager etter inngrepet (17). Vi har valgt å gi antibiotikaprofylakse per- og postoperativt $i$ vår egen praksis (1, 20), men det gjenstår å vurdere nytten av dette mer spesifikt for Bascoms operasjonsteknikk i fremtidige studier.

En studie fra introduksjonsfasen av denne teknikken ved Universitetssykehuset NordNorge indikerte lite postoperative smerter og en gjennomsnittlig sykmeldingsperiode på 11,5 dager etter inngrepet (20). I en tidlig fase med mange kirurger og derav en del rutinesvikt, oppnådde man likevel varig helbredelse hos $83 \%$ av pasientene ved kontroll etter 17 måneder og med få unntak uten supplerende kirurgi. I dag er rutinene betydelig forbedret ved at kirurgien er samlet på færre hender.

Som beskrevet ovenfor, er den vanligste komplikasjonen etter Bascoms kløft-løftoperasjon forsinket primær sårtilheling, mens residivraten er relativt lav $(10,12,20$, 32-34). Egne studier viser dessuten postoperative smerter i 2-3 dager etter inngrepet hos halvparten av pasientene (20). Andre rapporterer om minimal ømhet i sakralområdet hos $11 \%$ to år etter Bascoms operasjon (33) eller ingen smerter eller andre langtidsbivirkninger ti måneder etter inngrepet (34). Bascom rapporterer selv om én pasient med minimalt ubehag som følge av en langvarig sårtilheling (10). Hovedinntrykket er at Bascoms operasjon innebærer et minimalt smerteproblem på nivå med andre hudinngrep og kan ikke sammenliknes med smerter etter annen pilonidal kirurgi som innebærer dyp eksisjon ned til halebeinet.

\section{Konklusjon}

Pilonidal sykdom som oppstår i glutealkløften er en ufarlig, men plagsom sykdom som tradisjonelt sett har hatt dårlige behandlingsresultater. En gjennomsnittlig sykdomsperiode på seks år eller mer før kurativ kirurgi tyder på hyppige residiv og manglende kurativ behandling $(10,20)$. Innføring av bedre operasjonsteknikk kan endre residiv- 

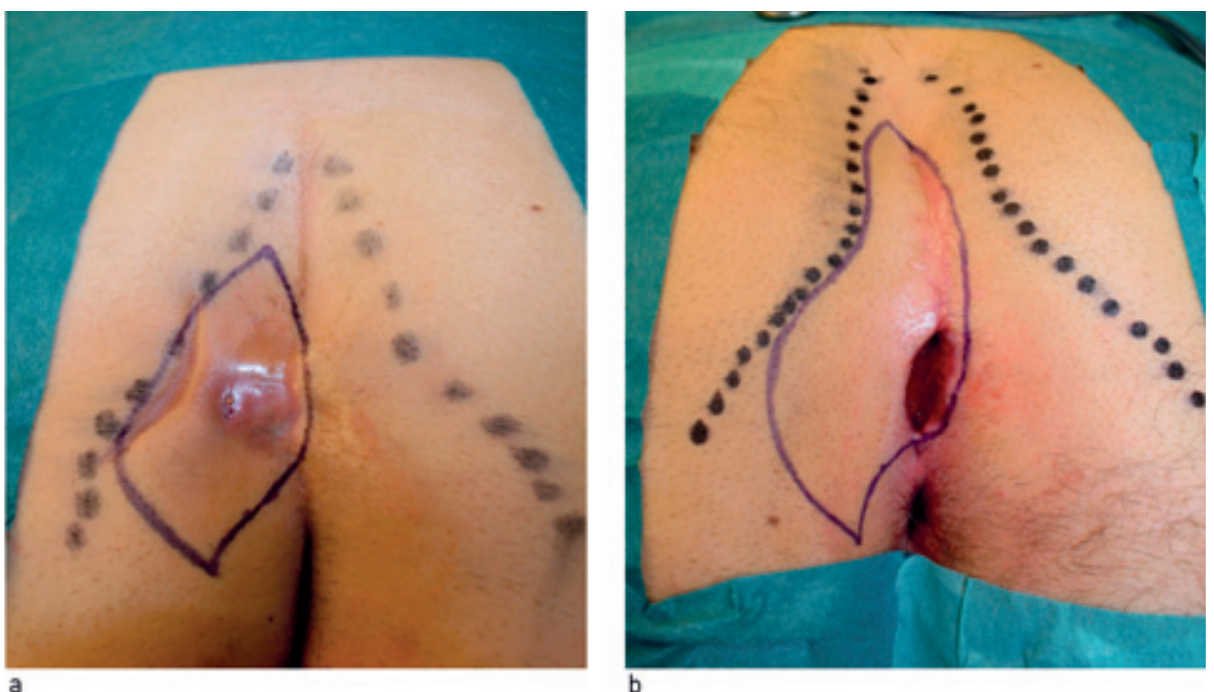

Figur 4 To ulike varianter av Bascoms kløft-løft-operasjon avhengig av den kraniokaudale utbredelsen av pilonidal sykdom. a) Hudforandringen, i form av en recidiverende abscess, ligger kranialt i rima i god avstand til anus og man resecerer derfor en mindre ellipse. Ved eventuelle laterale sinusåpninger lages skissen på den siden som gjør at disse innbefattes i preparatet. b) Hudforandringene (etter en tidligere mislykket midtlinjeoperasjonl ligger her mer kaudalt og man resecerer derfor en større ellipse der den kaudale del svinges bort fra anus for å unngå anus og lukkemuskulatur

raten. Det foreligger nå studier som indikerer at overflatisk, asymmetrisk reseksjon av hudlapp som inneholder hudåpninger etterfulgt av primær lukning av hud gir en god tilhelingsrate hos de fleste pasientene med denne sykdommen. Dyp eksisjon med sekundær granulasjonstilheling bør unngås hos pasienter med denne typen lidelse.

\section{Oppgitte interessekonflikter: Ingen}

\section{Litteratur}

1. Søreide K. The best surgical technique for chronic pilonidal disease - is this question still open, or closed? Nat Clin Pract Gastroenterol Hepatol 2009; 6: 20-2.

2. Bascom J. Pilonidal disease: origin from follicles of hairs and results of follicle removal as treatment. Surgery 1980; 87: 567-72.

3. Søndenaa K, Andersen E, Nesvik I et al. Patient characteristics and symptoms in chronic pilonidal sinus disease. Int J Colorectal Dis 1995: 10 : $39-42$.

4. Chintapatla S, Safarani N, Kumar S et al. Sacrococcygeal pilonidal sinus: historical review, pathological insight and surgical options. Tech Coloproctol 2003; 7: 3-8.

5. Hølmebakk T, Nesbakken A. Surgery for pilonidal disease. Scand J Surg 2005; 94: 43-6.

6. Tejirian T, Lee JJ, Abbas MA. Is wide local excision for pilonidal disease still justified? Am Surg 2007; 73: $1075-8$
7. Unalp HR, Derici H, Kamer E et al. Lower recurrence rate for Limberg vs. V-Y flap for pilonidal sinus. Dis Colon Rectum 2007; 50: 1436-44.

8. Anderson JH, Yip CO, Nagabhushan JS et al. Daycase Karydakis flap for pilonidal sinus. Dis Colon Rectum 2008; 51: 134-8

9. Petersen S, Koch R, Stelzner S et al. Primary closure techniques in chronic pilonidal sinus: A survey of the results of different surgical approaches. Dis Colon Rectum 2002; 45: $1458-67$.

10. Bascom J, Bascom T. Failed pilonidal surgery: new paradigm and new operation leading to cures. Arch Surg 2002: 137: 1146-50.

11. Aaser P, Grüner OP. Pilonidalcyste. Eksisjon og primær intrakutan resorberbar suture. Tidsskr Nor Lægeforen 1992; 112: 206-7.

12. Nordon IM, Senapati A, Cripps NPJ. A prospective randomized controlled trial of simple Bascom's technique versus Bascom's cleft closure for the treatment of chronic pilonidal disease. Am J Surg 2009; 197: 189-92.

13. McCallum I, King PM, Bruce J et al. Healing by primary versus secondary intention after surgical treatment for pilonidal sinus. Cochrane Database Syst Rev 2007; nr. 4: CD006213.

14. McCallum I, King PM, Bruce J. Healing by primary closure versus open healing after surgery for pilonidal sinus: systematic review and meta-analysis. BMJ 2008; 336: 868-71.

15. Chaudhuri A, Bekdash BA, Taylor AL. Single-dose metronidazole vs 5 -day multi-drug antibiotic regimen in excision of pilonidal sinuses with primary ded pilot study. Int J Colorectal Dis 2006; 21: $688-92$. closure: a prospective, randomized, double-blin-
16. Søndenaa K, Nesvik I, Gullaksen FP et al. The role of cefoxitin prophylaxis in chronic pilonidal sinus treated with excision and primary suture. J Am Coll Surg 1995; 180: 157-60.

17. Lundhus E. Gjøde P Gottrup F et al. Bactericidal antimicrobial cover in primary suture of perianal or pilonidal abscess. A prospective, randomized, double blind clinical trial. Acta Chir Scand 1989. 155: $351-4$.

18. Füzün M, Bakir $H$, Soylu $M$ et al.Which technique for treatment of pilonidal sinus - open or closed? Dis Colon Rectum 1994; 37: 1148-50.

19. Akca T, Colak T, Ustonsoy B et al. Randomized clinical trial comparing primary closure with the Limberg flap in the treatment of primary sacrococcygeal pilonidal disease. Br J Surg 2005; 92; $1081-4$.

20. Rushfeldt C, Bernstein A, Norderval S et al. Introducing an asymmetric cleft lift technique as a uniform procedure for pilonidal sinus surgery. Scand J Surg 2008; 97: 77-81.

21. Akinci OF, Bozer M, Uzunköy A et al. Incidence and aetiological factors in pilonidal sinus among Turkish soldiers. Eur J Surg 1999; 165: 339-42.

22. Arda IS, Güney LH, Sevmi? S et al. High body mass index as a possible risk factor for pilonidal sinus disease in adolescents. World J Surg 2005; 29: 469-71.

23. da Silva JH. Pilonidal cyst: cause and treatment. Dis Colon Rectum 2000; 43: 1146-56.

24. Al-Khayat H, Sadeq A, Groof A et al. Risk factors for wound complication in pilonidal sinus procedures. J Am Coll Surg 2007; 205: 439-44.

25. Bascom JU. Pilonidal care: anaerobes as invisible villains. Eur J Surg 1996; 162: 351

26. Karydakis GE. Easy and successful treatment of pilonidal sinus after explanation of its causative process. Aust N Z J Surg 1992; 62: 385-9.

27. Doll D, Friederichs J, Dettmann $\mathrm{H}$ et al. Time and rate of sinus formation in pilonidal sinus disease. Int J Colorectal Dis 2008; 23: 359-64.

28. Søndenaa K, Pollard ML. Histology of chronic pilonidal sinus. APMIS 1995; 103: 267-72.

29. Søndenaa K, Nesvik I, Andersen E et al. Bacteriology and complications of chronic pilonidal sinus treated with excision and primary suture. Int J Colorectal Dis 1995; 10: 161-6.

30. Classic articles in colonic and rectal surgery. Louis A. Buie, M.D. 1890-1975. Jeep disease (pilonidal disease of mechanized warfare). Dis Colon Rectum 1982: 25: 384-90.

31. Bascom JU. Repeat pilonidal operations. Am J Surg 1987; 154: 118-21

32. Bascom J, Bascom T. Utility of the cleft lift procedure in refractory pilonidal disease. Am J Surg 2007. 193: 606-9.

33. Abdelrazeq AS, Rahman M, Botterill ID, Alexander DJ. Short-term and long-term outcomes of the cleft lift procedure in the management of nonacute pilonidal disorders. Dis Colon Rectum 2008; 51: 1100-6.

34. Theodoropoulos GE, Vlahos K, Lazaris A et al. Modified Bascom's asymmetric midgluteal cleft closure technique for recurrent pilonidal disease early experience in a military hospital. Dis Colon Rectum 2003; 46: 1286-91.

Manuskriptet ble mottatt 8.3. 2009 og godkjent 28.1. 2010. Medisinsk redaktør Siri Lunde. 